\author{
반추가축영양에 있어서 액상미생물제제의 첨가가 In Vitro \\ 발효성상과 섬유소분해효소활성에 미치는 영향 \\ 이성훈*·서인준** \\ 한국농업전문학교 축산학과*, 우텍(주)**
}

\title{
Effects of Supplementing Aqueous Direct-Fed Microbials on In Vitro Fermentation and Fibrolytic Enzyme Activity in the Ruminant Nutrition
}

\author{
S. H. Lee* and I. J. Seo** \\ Department of Animal Science, Korea National Agricultural College, RDA, Suwon 445-893, Korea* \\ Woo Tech Co., Yongin 102-104, Korea**
}

\begin{abstract}
This study was conducted to determine effects of supplementation levels of aqueous direct-fed microbials (DFM; Bacillus spp.) to TMR (exp. 1.) and aqueous DFM addition under the various ratios of starch and cellulose (exp. 2.) on ruminal fermentation and fibrolytic enzyme activity. In experiment 1, ruminal fluids taken from rumen-cannulated Holstein cows were incubated during $24 \mathrm{hr}$ by using TMR as substrates. Aqueous DFM was applied at a rate of $0,0.025$ and $0.05 \%$, respectively. The $\mathrm{pH}$ of $0.025 \%$ treatment was not significantly different from that of control at 6 and $9 \mathrm{hr}$, but it was significantly lower $(\mathrm{P}<0.05)$ than $0.05 \%$ treatment.

Concentrations of ammonia- $\mathrm{N}$ and VFAs were not affected by supplementing aqueous DFM. The A:P ratio of $0.05 \%$ treatment was significantly increased $(\mathrm{P}<0.05)$ by supplementation of aqueous DFM as compared with that of control at $24 \mathrm{hr}$. Although overall fibrolytic enzyme activities were not significantly affected by supplementing aqueous DFM, CMCase (carboxymethylcellulase) activity showed significant increase $(\mathrm{P}<0.05)$ compared to control at $6 \mathrm{hr}$. However, the xylanase activity of $0.05 \%$ treatment significantly decreased $(\mathrm{P}<0.05)$ at $12 \mathrm{hr}$ due to the application of aqueous DFM. There was no significant difference for in vitro dry matter disappearance among treatments.

In experiment 2, ruminal fluids were incubated under the condition of various ratios of starch to cellulose $(90: 10,70: 30,50: 50,30: 70$ and 10:90) with or without aqueous DFM(0.025\%). Ruminal pH was
\end{abstract}

Corresponding author:S. H. Lee, Department of Animal Science, Korea National Agricultural College, RDA, Suwon 445-893, Korea. Tel :+82-11-9639-5037, Fax :+82-31-229-5055. E-mail :sh5037@, hanmail.net 
unaffected by the addition of aqueous DFM, however, as increased level of starch, ruminal pH partially showed significant decrease $(\mathrm{P}<0.05)$. Ammonia-N concentration was not affected by aqueous DFM and ratio of starch and cellulose. On $9 \mathrm{hr}$ incubation, DFM addition at a ratio of 70:30 showed significantly $(\mathrm{P}<0.05)$ lower value of ammonia-N $(35.65 \mathrm{mg} / \mathrm{dL})$ than that $(65.05 \mathrm{mg} / \mathrm{dL})$ of control. Concentrations of VFAs were significantly increased $(\mathrm{P}<0.05)$ by aqueous $\mathrm{DFM}$ addition compared with control at the same ratio on $6 \mathrm{hr}$ incubation. The overall CMCase activity was not affected by aqueous DFM addition. However, the xylanase activity by aqueous DFM partially showed significant differences at the ratios of 90:10, 30:70 and 10:90.

Our results indicated that supplementation of aqueous DFM did not significantly improve in vitro fermentation and fibrolytic enzyme activity. In addition, the DFM utilized in this study did not show consistent results by having various effects on ruminal fermentation under different feeding regimens.

(Key words : Aqueous direct-fed microbials, Bacillus spp., Ruminal fermentation, CMCase, Xylanase)

\section{I. 서 론}

반추동물에서 반추위내 미생물의 발효조절을 최적화하여 생산성을 최대화하기 위해 다양한 시도가 있어 왔다. 이를테면 반추위내 메탄생 성억제제, ionophore계 항생제의 이용은 반추동 물의 생산성에 있어 반추위내 메탄생성으로 인 한 영양소 손실을 줄이고, 최적의 발효상태를 유지시켜 가축의 생산성에 커다란 이익을 가져 왔다 (Sauer 등, 1989; Jalc 등, 1991). 이와 더불 어 동물성장촉진이나 장내 미생물의 균형 및 병원균에 대한 면역기능을 향상시킨다는 미생 물제제의 관심 또한 증가하였다(Kung, 2001). 기본적으로 동물사료에 보충되는 미생물제제는 생균제 (probiotics)로서, 미국 FDA (Food \& Drug Administration)에서는 사료제조업자들이 생균제 대신에 direct-fed microbials(DFM)이라는 용어를 사용할 것을 요구하였다(Miles와 Bootwalla, 1991).

생균제 및 $\mathrm{DFM}$ 에 대한 작용기전은 단위동물 영양 뿐만 아니라 반추동물영양분야 연구자에 의해 제시된 바 있고, 단위동물에서 그 기전은 장내상피세포에 부착되어 있는 수용체에 대한 경합(Jonsson과 Conway, 1992), 영양소에 대한 경합(Freter, 1992), 항생물질의 생산(Hentges, 1992), 면역자극효과(Perdigon과 Alvarez, 1992) 등으로 보고되고 있다.

한편, 반추동물의 사료에 보충되는 fungal 및 bacterial DFM에 대한 연구는 착유우와 비육우 에서 산유량 및 증체량 뿐만 아니라 사료효율 을 향상시키고(Yoon과 Stern, 1995), Kung (2001) 은 장내 병원균의 번식을 억제시켜 동물의 건 강과 항생제 대체사용의 역할을 하여 축산물에 대한 소비자의 안전성을 기대할 수 있다고 보 고하였다.

반추동물사료에서 $\mathrm{DFM}$ 은 동물의 생산성과 연계하여 특정 효소 즉, 사료내 섬유소의 분해 활성을 목적으로 여러 가지 미생물제가 이용되 고 있다(Beauchemin 등, 2001). DFM은 반추동 물용 사료에 $0.01 \sim 1 \%$ 내외로 적은 적용비율에 도 불구하고 가축의 생산성에 긍정적인 효과를 나타낸다고 시사하였지만(McAllister 등, 1999), 반추위내 이들의 작용기전에 대한 충분한 자료 가 부족하고 그 효과의 유효수준, 사료의 조성, 사료급여체계, 동물의 성장단계 및 소화기관내 작용부위에 따라 기전이 다양하여 일관된 결과 를 나타내지 못하며, 미생물효소제에 대한 반 추동물의 반응 또한 다양하게 나타난다(Yang 등, 1999; Phipps 등, 2000; Sutton 등, 2003).

이에 따라 본 연구에서는 시판되고 있는 Bacillus spp. 배양물을 반추동물사료에 첨가하 여 반추위발효를 평가하고자 한다. Bacillus는 자연계에 널리 분포하는 균종으로서, 단백질, 지방 및 탄수화물 (전분 및 섬유소) 분해활성이 높은 것으로 알려져 있다(Kalogridou-Vassiliadou, 1992). 하지만, 반추동물에 대한 DFM으로서 
Bacillus spp.의 반추위내 발효 및 사양성적에 대한 효과보고는 거의 전무한 실정이다. 일부 연구에서 송아지 및 면양을 대상으로 Bacillus 균을 급여하였을 때, 사료효율 및 증체율이 개 선되는 것으로 보고하고 있으나(Jenny 등, 1991; Rojo 등, 2005), 그 효과 또한 명확하지 않아 더 많은 연구가 절실하다. 또한 반추동물에 있 어 $\mathrm{DFM}$ 의 효과에 미치는 인자는 다양하고, 그 중 사료의 조성 및 급여사료의 종류에 따라 그 효과가 달라지는 것으로 알려져 있다(Rode, 등, 1999; Yang 등, 1999; Yang 등, 2000).

따라서, 본 연구에서는 시판중인 액상 $\mathrm{DFM}$ (Bacillus spp.)을 반추동물용 완전혼합사료에 수 준별로 적용하였을 때(실험 1)와 사료내 starch 와 cellulose의 비율을 다양하게 배합하여 적용 하였을 때(실험 2), in vitro 반추위발효와 섬유 소분해효소활성에 미치는 영향을 조사하였다.

\section{II. 재료 및 방법}

본 실험은 액상 $\mathrm{DFM}$ 이 반추위내 발효와 섬 유소분해효소활성에 미치는 영향을 조사하기 위해 두 개의 실험으로 나누어 실시하였고, 실 험1은 자가 배합한 완전혼합사료(total mixed ration)에 대한 액상 $\mathrm{DFM}$ 적용수준 실험이었고, 실험 2는 starch와 cellulose의 배합비율을 달리 하였을 때 액상 $\mathrm{DFM}$ 의 기질조성에 따른 효과 실험이었다. 실험 1과 2는 반추위혼합미생물에 의한 in vitro 배양장치에서 실시하였다.

\section{1. 실험설계 및 액상 DFM}

실험 1 은 0 (대조구), 0.025 및 $0.05 \%$ 의 액상 $\mathrm{DFM}$ 을 완전혼합사료에 각각 첨가하여 배양을 실시하는 것으로서 처리구를 세 수준으로 설정 하였고, 각 처리구당 3 반복하여 완전임의배치 법으로 실시하였다. 실험 2는 $\operatorname{starch}(\mathrm{S})$ 와 cellulose (C)를 90:10, 70:30, 50:50, 30:70, 10:90의 비율 로 $\mathrm{S}: \mathrm{C}$ 비율에 대하여 각각 액상 $\mathrm{DFM}$ 을 첨가 하여 $5 \times 2$ 의 요인실험으로 설험설계를 하였고, 각 처리구간 반복은 실험 1 과 동일하였다. 실 험2의 액상 $\mathrm{DFM}$ 첨가율은 공급사 (BioSmart ${ }^{\circledR}$,
USA)의 권장수준 $(0.025 \%)$ 에 준하여 첨가하였 다.

\section{2. 배양기질의 준비 및 액상 DFM 첨가}

실험 1 의 배양에 사용된 완전혼합사료의 배 합원료 및 화학적 조성은 Table 1에 나타내었 다. 이는 배양을 위해 $60^{\circ} \mathrm{C}$ drying oven(Hanbaek Scientific Co., Korea)에 48시간 건조 후, $1 \mathrm{~mm}$

Table 1. Ingredients and chemical compositions of total mixed ration used in experiment ${ }^{1)}$

\begin{tabular}{lc}
\hline Item & $\begin{array}{c}\text { Total mixed } \\
\text { ration }\end{array}$ \\
\hline \hline Ingredient composition & $\ldots \%$ of DM $\cdots$ \\
Cracked corn & 17.89 \\
Corn gluten feed & 7.16 \\
Beet pulp & 8.21 \\
Lupin hull & 1.03 \\
Corn bran & 11.15 \\
Soybean meal & 10.03 \\
Brewers' grain & 8.13 \\
Sesame meal & 2.12 \\
Whole cottonseed & 6.22 \\
Hay mixture & 22.47 \\
Sugarcane molasses & 3.24 \\
Vitamin/mineral mixture ${ }^{2)}$ & 2.35 \\
Chemical composition & \\
Crude protein (CP) & 16.77 \\
Nonfibrous carbohydrate & 38.05 \\
Neutral detergent fiber (NDF) & 35.13 \\
Ether extract (EE) & 4.66 \\
Crude ash & 7.35 \\
Calcium & 0.61 \\
Phosphorus & 0.44 \\
\hline Coined &
\end{tabular}

${ }^{1)}$ Contained tall fescue straw, oat hay, and bermuda hay;

2) contained $2.85 \% \mathrm{Ca}, 1.31 \% \mathrm{P}, 1.18 \% \mathrm{Na}, 0.4 \% \mathrm{Mg}$, $2.63 \% \mathrm{~K}, 238,000 \mathrm{IU}$ vitamin $\mathrm{A}$, and 57,000 IU vitamin $\mathrm{D}$;

${ }^{3)}$ nonfibrous carbohydrate content was calculated as 100 $-(\mathrm{CP}+\mathrm{EE}+\mathrm{NDF}+\mathrm{ash})$. 
screen이 장착된 Wiley mill로 분쇄하여 미세입 자는 제거하여 배양기질로 사용하였다. 실험 2 에 사용된 배양기질은 탄수화물원으로서 starch (corn starch: wheat starch $=1: 1$ 로 혼합하여 이 용)와 cellulose의 비율을 90:10, 70:30, 50:50, 30:70 및 10:90으로 다르게 배합하였고, 질소원 으로는 요소(urea)를 사용하여 처리구간 조단백 질기준으로 $17 \%$ 함유하도록 동일하게 하였다. 본 실험에 사용된 액상 $\mathrm{DFM}$ 은 현재 상업적으 로 시판중인 미생물제제 $\left(\mathrm{BioSmart}{ }^{\mathrm{R}}\right.$, USA)로서 미생물종은 Bacillus spp. $\left(3 \times 10^{6} \mathrm{cfu} / \mathrm{mL}\right)$ 이었다. 실험 1 의 액상 $\mathrm{DFM}$ 은 처리구의 기질이 공급된 배양병에 각각 0.025 와 $0.05 \%$ 로 각각 첨가한 후 혼합하여 사용하였고, 적용되는 $\mathrm{DFM}$ 비율이 소량이므로 액상 $\mathrm{DFM}$ 을 증류수에 희석하여 원 액기준으로 첨가하였다. 실험 2 는 실험1과 동 일한 방법으로 첨가하였다.

\section{Rumen Inoculum 준비와 배양방법}

배양에 사용된 rumen inoculum은 반추위 cannulae가 장착된 홀스타인 젖소로부터 얻어 실험실로 운반하였다. 운반하는 동안은 $39^{\circ} \mathrm{C}$ 로 유지된 보온병에 잘 보관하였고, 운반 후 즉시 반추위 내용물은 사료입자를 제거하기 위해 2 겹 cheesecloth에 여과하였고, $20 \mathrm{~L}$ 용량의 Pyrex 병에 $39^{\circ} \mathrm{C}$ 로 유지하여 보관하였다. 여과된 반 추위내용물은 $\mathrm{CO}_{2}$ 로 bubbling한 rumen buffer용 액과 1:1로 혼합하여 이를 rumen inoculum으로 사용하였다.

Rumen buffer용액은 Maeng 등(1976)의 방법 으로 제조하여 사용하였다. 배양은 Tilly와 Terry (1963)의 방법을 개량한 Maeng 등(1976)의 방법 에 따라 실시하였으며, $1 \mathrm{~L}$ 용 narrow-mouth bottle(Nalgen Co., USA)에 $500 \mathrm{~mL}$ 의 rumen inoculum을 천천히 주입시키며 $39^{\circ} \mathrm{C} \pm 0.5$ 로 설정 된 항온교반기(Sangwoo Co., Korea)에서 100 $\mathrm{rpm}$ 으로 교반하면서 배양하였으며, 배양시간은 $3,6,9,12,24$ 시간으로 하였고, 기질은 ruminal fluid volume의 $2 \%$ 를 공급하였다.

4. 분석항목 및 분석방법
배양에 이용된 기질의 영양성분은 $\mathrm{AOAC}$ (1995)의 방법에 따라 건물과 조단백질, 에테르 추출물, 칼슘 및 인 함량을 분석하였고, $\mathrm{NDF}$ (neutral detergent fiber)함량은 Van Soest 등 (1991)의 방법에 따라 분석하였다. 배양한 후에 각 배양물을 $\mathrm{pH}$ meter(WTW Co., Germany)를 사용하여 $\mathrm{pH}$ 를 측정한 후 sample을 $-20{ }^{\circ} \mathrm{C}$ 에서 분석시까지 냉동보관하였고, rumen parameter의 측정시 냉동보관해 두었던 sample을 $5^{\circ} \mathrm{C}$ 로 녹 인 즉시 약 $20 \mathrm{~mL}$ 의 위액을 취하여 $1,500 \times \mathrm{g}$ 로 15 분간 원심 분리하여 상층액과 pellet으로 분 리한 후 상층액으로 암모니아질소농도와 휘발 성지방산분석에 사용하였다. 암모니아질소의 분 석은 Chaney와 Marbach(1962)의 방법에 따라 phenol과 alkali를 각각 $1 \mathrm{~mL}$ 씩 취하여 상층액 $20 \mu \mathrm{L}$ 에 첨가하여 vortexing하였다. 이를 $60^{\circ} \mathrm{C}$ dry oven(Hanbaek Scientific Co., Korea)에서 5 분 간 배양하여 발색반응을 일으켰고, 이 후 증류 수 $8 \mathrm{~mL}$ 를 추가하여 vortexing하였다. 증류수로 희석된 발색시료는 spectrophotometer (Shimadzu, Japan)를 이용하여 $630 \mathrm{~nm}$ 에서 흡광도를 측정하 여 암모니아질소농도를 계산하였다. 휘발성지 방산은 Erwin 등(1961)의 방법에 따라 상층액 1 $\mathrm{mL}$ 에 $25 \%$ metaphosphoric acid $100 \mu \mathrm{L}$ 를 첨가 하고, $3,000 \mathrm{rpm}$ 에서 15 분간 원심분리한 후 상 층액을 gas chromatography (Hewlett Packard 6890, Hewlett Packard Co.)에 주입하여 분석하였다. 휘발성지방산분석에 사용된 column은 $30-\mathrm{m}$ capillary column(Stabilwax-DA, $0.53 \mathrm{~mm}$ ID; Restek Corporation, Bellefonte, PA)이었고, detector는 FID(flame ionization detector) 이었다. Gas chromatography의 분석조건은 injector와 detector온도가 각각 $200^{\circ} \mathrm{C}$ 와 $250^{\circ} \mathrm{C}$ 이었으며, column온도는 $180^{\circ} \mathrm{C}$ 로 유지시켰다. Carrier gas로서 $\mathrm{N}_{2}$ 를 사용 하여 flow rate는 분당 $30 \mathrm{~mL}$ 가 되도록 하였고, split ratio는 $30: 1$ 로 하였으며, 운용시간은 8.5 분 으로 조정하였다. 건물소실율은 실험 1 의 배양 12 시간과 24시간에서 각각 nylon bag을 이용하 여 digesta를 여과하여 tap water에 세척한 후 $60^{\circ} \mathrm{C}$ drying oven에 건조하여 무게감소차이로 소실율을 계산하였다. 섬유소분해효소활력(CMCase, xylanase)의 측정은 Miller(1959)의 방법에 따라, 
효소액 $0.2 \mathrm{~mL}$ 와 기질용액으로 $1 \%(\mathrm{w} / \mathrm{v}) \mathrm{CMC}$ 또는 $2 \%$ 의 oat spelt xylan이 현탁된 $0.1 \mathrm{M}$ acetate buffer(pH 5.0)를 혼합하여 $1 \mathrm{~mL}$ 가 되게 한 후, $55^{\circ} \mathrm{C}$ 에서 30 분간 반응시키고 $100^{\circ} \mathrm{C}$ 에서 5 분간 진탕하여 반응을 중지시킨 다음 상등액 내의 환원당의 양을 DNS(dinitrosalicylic acid)법 을 이용하여 $550 \mathrm{~nm}$ 에서 흡광도를 측정하였다. CMCase의 1 unit는 1 분 동안 $1 \mu \mathrm{mole}$ 의 glucose 를 생성하는 효소의 양을 나타내고, xylanase의 1 unit는 1 분 동안 1 umole의 xylose를 생성하 는 효소의 양을 나타낸다.

\section{5. 통계분석}

실험 1 에서 얻어진 결과는 SAS package program(2000, release. 8.1 version)의 GLM (general linear model) procedure를 이용하여 분 석하였고, 실험 2는 ANOVA(analysis of variance) procedure를 이용하여 요인분석을 하였다. 처리 구간의 평균비교는 Duncan의 다중검정(Duncan, $1955)$ 에 의해 probability(P)값 $5 \%(0.05)$ 수준에
서 유의성을 검정하였다(Steel과 Torrie, 1980).

\section{III. 결과 및 고찰}

1. 실험 1

실험 1은 완전혼합사료에 액상 DFM적용수준 이 반추위발효성상과 섬유소분해효소 활성에 미치는 영향을 조사하였고, 액상 $\mathrm{DFM}$ 이 반추 위 $\mathrm{pH}$ 와 암모니아질소농도에 미치는 영향은 Table 2에 나타내었다. $\mathrm{pH}$ 는 배양 3, 6시간에 액상 $\mathrm{DFM}$ 에 의하여 유의한 효과가 나타나지 않았고, 배양 9시간과 12 시간에서 공히 액상 DFM $0.025 \%$ 적용구가 대조구와 유의한 차이는 없고, $0.05 \%$ 적용구 보다는 유의하게 감소하였 다 $(\mathrm{P}<0.05)$. 배양 9 시간 및 12 시간의 $0.025 \%$ 구 에서 $\mathrm{pH}$ 의 감소는 반추위미생물 및 액상 $\mathrm{DFM}$ 에 의한 기질분해로 생성된 총휘발성지방산생 성증가로 기인한 결과로 생각되고, 액상 $\mathrm{DFM}$ 이 분비하는 효소가 반추위내 사료의 분해에 작용한 것으로 사료된다. 하지만, 액상 $\mathrm{DFM}$ 첨

Table 2. Effects of aqueous DFM supplementation levels on in vitro ruminal $\mathrm{pH}$ and ammonia-N concentration

\begin{tabular}{|c|c|c|c|c|c|}
\hline \multirow{2}{*}{$\begin{array}{l}\text { Incubation time } \\
(\mathrm{hr})\end{array}$} & \multicolumn{3}{|c|}{ Treatments $^{1)}$} & \multirow{2}{*}{$\mathrm{SEM}^{2)}$} & \multirow{2}{*}{$P$-value } \\
\hline & Control & $0.025 \%$ & $0.05 \%$ & & \\
\hline 3 & 6.43 & 6.47 & 6.45 & 0.03 & 0.4867 \\
\hline 6 & 6.30 & 6.25 & 6.33 & 0.03 & 0.1448 \\
\hline 9 & $6.06^{\mathrm{ab} 3)}$ & $6.03^{\mathrm{b}}$ & $6.08^{\mathrm{a}}$ & 0.01 & 0.0477 \\
\hline 12 & $5.88^{\mathrm{ab}}$ & $5.81^{\mathrm{b}}$ & $5.95^{\mathrm{a}}$ & 0.03 & 0.0420 \\
\hline 24 & 5.58 & 5.53 & 5.52 & 0.03 & 0.2491 \\
\hline \multicolumn{6}{|c|}{$\ldots \ldots \cdots \cdots \cdots \cdots \cdots \cdot$ Ammonia-N, mg/dL $\cdots \cdots \cdots \cdots \cdots \cdots \cdots$} \\
\hline 3 & 5.72 & 7.95 & 5.87 & 1.19 & 0.2617 \\
\hline 6 & 31.31 & 17.77 & 22.48 & 8.51 & 0.3949 \\
\hline 9 & 28.90 & 26.71 & 25.90 & 1.93 & 0.3928 \\
\hline 12 & 47.85 & 43.80 & 46.99 & 2.54 & 0.3755 \\
\hline 24 & 47.82 & 43.49 & 42.01 & 5.70 & 0.6235 \\
\hline
\end{tabular}

1) All values represent the mean of triplicates; ${ }^{2)}$ standard error of the mean; ${ }^{3) \text { a,b }}$ means in the same row with different superscripts $\operatorname{differ}(\mathrm{P}<0.05)$. 
가수준의 증가가 $\mathrm{pH}$ 에 미치는 영향은 일정한 경향을 보이지 않았다. 일반적으로 시판되는 $\mathrm{DFM}$ 이 분비하는 효소는 주로 섬유소분해효소 (xylanase, cellulase, cellulose 1,4- $\beta$-cellobiosidase, $\beta$-glucanase, $\beta$-glucosidase, $\beta$-xylosidase) 뿐만 아니라, 단백질분해효소 및 전분분해효소 를 분비하고, 이들의 효과는 반추위내에서 단 독으로 강력하게 작용하는 것이 아니라, 반추 위내 미생물에 의한 endogenous enzyme이 주로 작용하고, 이들 $\mathrm{DFM}$ 이 분비하는 exogenous enzyme은 endogenous enzyme의 작용을 보조하 여 서로간의 공동작용(synergy)에 의해 나타나 는 것으로 알려져 있다(Beauchemin 등, 2001).

암모니아질소농도는 액상 $\mathrm{DFM}$ 의 첨가로 처 리구간 유의한 차이가 나타나지 않았다. DFM 의 exogenous enzyme의 첨가는 여러 연구 (Hristov 등, 1998, 2000)에서 반추위내 암모니아 질소농도가 증가하는 것으로 나타났고, 이는 효소에 의한 사료내 단백질분해가 증가하여 암 모니아질소농도가 증가하였다고 보고하였으며, 본 연구에 사용된 액상 DFM인 Bacillus는 단백 질분해에 유의한 영향을 미치지 않는 것으로 나타났다. Luchini 등(1996)은 Bacillus 균이 $\mathrm{pH}$ 7내지 9 범위에서 최적의 단백질분해효소활성 을 가진다고 보고하였고, 이는 본 실험에서 나 타난 $\mathrm{pH}$ 와 상이하였으며, 그 결과 암모니아질 소농도가 수준별 첨가구간에 차이가 없었던 것 으로 생각된다.

액상 $\mathrm{DFM}$ 이 반추위내 휘발성지방산농도에 미치는 영향은 Table 3에 나타내었다. 액상 $\mathrm{DFM}$ 은 총휘발성지방산농도에 유의한 영향을 미치지 않았다. Krause 등(1998)은 육성우에 보 리를 기초로 한 사료에서 효소의 첨가에 의해 전 장관소화율이 증가함에도 불구하고, 반추위 내 $\mathrm{pH}$ 및 휘발성지방산농도에 유의한 영향이 없었다고 보고하였고, 다른 연구자(Rust 등, 1965; Arambel과 Wiedmeier, 1986; Feng 등, 1996) 또한 유사한 연구결과를 보고하여 본 실험결과 와 일치하였으며, DFM이 분비하는 exogenous enzyme이 반추위내 발효에 유의한 영향을 미치 지 않는 것으로 나타났다. 하지만, 배양 12 시간 이후로 휘발성지방산농도가 수치상으로 증가하
는 경향을 나타내었다. 특히 valeric acid와 A:P 비율은 대조구에 비하여 첨가구가 유의하게 증 가하는 것으로 나타났다 $(\mathrm{P}<0.05)$. 본 실험에서 액상 $\mathrm{DFM}$ 이 반추위내 발효성상에 대한 효과는 유의하지 않았지만, 휘발성지방산이 전반적으 로 증가하는 경향을 나타내었고 $(\mathrm{P}>0.05)$, 액상 $\mathrm{DFM}$ 이 배양 24 시간의 $0.05 \%$ 첨가구에서 반추 위내 $\mathrm{A}: \mathrm{P}$ 비율을 증가시키는 것으로 나타났다 $(\mathrm{P}<0.05)$.

액상 DFM이 반추위내 섬유소분해효소활성과 건물소실율에 미치는 영향은 Table 4에 나타내 었다. 액상 $\mathrm{DFM}$ 으로 인한 섬유소분해효소 활성 과 건물소실율은 반추위내에서 전체적으로 유 의한 차이는 없었으나, CMCase(carboxymethylcellulase)는 배양 6시간에서 대조구의 15.09에 비하여 첨가구에서 각각 17.83 과 18.13 unit의 활력을 나타내어 액상 $\mathrm{DFM}$ 의 첨가가 효소활성 에 유의한 증가를 나타내었다 $(\mathrm{P}<0.05)$. 하지만, xylanase는 액상 $\mathrm{DFM}$ 의 적용으로 배양 12 시간 에 대조구에 비하여 $0.05 \%$ 첨가구가 유의하게 감소하였다 $(\mathrm{P}<0.05)$.

Hristov 등(1998)은 exogenous enzyme을 반추 동물에 적용시 여러 가지 환경에 의해 효소의 작용이 제한을 받고, exogenous polysaccharidedegrading enzyme에 대한 CMCase와 xylanase활 성은 거의 반추위내에서 효과가 나타나지 않았 으며, 반추위내에서 보다는 십이지장에서 섬유 소분해효소활성이 증가하는 결과를 보고하였 고, 이는 $\mathrm{pH}$ 에 의해 효소의 안정성(stability)이 영향을 받는다고 하였다.

일반적으로 exogenous enzyme과 DFM의 반추 동물사료내 첨가는 반추위내 미생물이 이용 가 능한 환원당의 농도를 증가시키고, 그 결과로 서 사료내 반추위분해단백질과 발효동조화현상 이 나타나 미생물단백질합성량이 증가하며, 아 울러 반추위 미생물에 의한 소화율이 증가할 뿐만 아니라 산유성적 또한 개선되는 것으로 보고되고 있다(Hristov 등, 1998; Rode 등, 1999; Wang 등, 2001). 반추위내 건물소실율은 액상 $\mathrm{DFM} 0.025$ 및 $0.05 \%$ 구에서 각각 55.20 및 $54.88 \%$ 로 대조구의 $54.51 \%$ 보다 유의하지는 않 았지만 다소 증가하였고, 본 실험에서 액상 
Table 3. Effects of aqueous DFM supplementation levels on in vitro volatile fatty acids concentrations

\begin{tabular}{|c|c|c|c|c|c|}
\hline \multirow{2}{*}{$\begin{array}{l}\text { Incubation } \\
\text { time (hr) }\end{array}$} & \multicolumn{3}{|c|}{ Treatments $^{1)}$} & \multirow{2}{*}{$\mathrm{SEM}^{2)}$} & \multirow{2}{*}{$P$-value } \\
\hline & Control & $0.025 \%$ & $0.05 \%$ & & \\
\hline \multicolumn{6}{|c|}{ 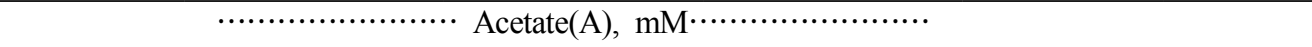 } \\
\hline 3 & 40.15 & 43.63 & 42.37 & 5.67 & 0.8337 \\
\hline 6 & $56.39^{\mathrm{a} 3)}$ & $47.36^{\mathrm{b}}$ & $50.97^{\mathrm{ab}}$ & 2.49 & 0.0482 \\
\hline 9 & 59.80 & 56.11 & 58.78 & 6.57 & 0.8522 \\
\hline 12 & 56.40 & 68.82 & 62.36 & 11.38 & 0.6057 \\
\hline \multirow[t]{2}{*}{24} & 68.62 & 76.81 & 84.22 & 5.96 & 0.1680 \\
\hline & \multicolumn{4}{|c|}{ 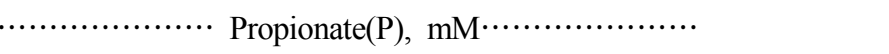 } & \\
\hline 3 & 15.61 & 17.07 & 16.07 & 2.48 & 0.8431 \\
\hline 6 & 21.61 & 19.37 & 20.34 & 1.43 & 0.4079 \\
\hline 9 & 23.52 & 21.91 & 22.65 & 2.95 & 0.8675 \\
\hline 12 & 20.50 & 25.51 & 23.05 & 4.75 & 0.6233 \\
\hline \multirow[t]{2}{*}{24} & 27.34 & 30.38 & 32.32 & 2.32 & 0.2444 \\
\hline & \multicolumn{4}{|c|}{ 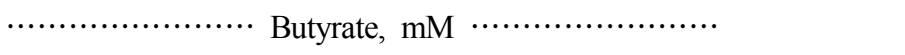 } & \\
\hline 3 & 9.34 & 9.92 & 9.55 & 1.22 & 0.8926 \\
\hline 6 & 13.36 & 11.35 & 12.15 & 0.68 & 0.1259 \\
\hline 9 & 15.36 & 13.28 & 13.68 & 1.53 & 0.4530 \\
\hline 12 & 13.38 & 16.12 & 14.65 & 3.13 & 0.7099 \\
\hline \multirow[t]{2}{*}{24} & 18.01 & 19.65 & 20.98 & 1.42 & 0.2580 \\
\hline & \multicolumn{4}{|c|}{ n................... Valerate, $\mathrm{mM}$. } & \\
\hline 3 & 1.84 & 2.01 & 1.96 & 0.30 & 0.8561 \\
\hline 6 & 2.27 & 2.12 & 2.19 & 0.14 & 0.6161 \\
\hline 9 & 2.85 & 2.42 & 2.48 & 0.38 & 0.5362 \\
\hline 12 & 2.48 & 3.21 & 2.86 & 0.58 & 0.5267 \\
\hline \multirow[t]{2}{*}{24} & $3.72^{b}$ & $4.10^{\mathrm{ab}}$ & $5.04^{\mathrm{a}}$ & 0.38 & 0.0434 \\
\hline & \multicolumn{4}{|c|}{ 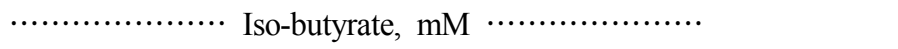 } & \\
\hline 3 & 1.26 & 1.39 & 1.31 & 0.23 & 0.8695 \\
\hline 6 & 1.65 & 1.48 & 1.59 & 0.09 & 0.2996 \\
\hline 9 & 2.04 & 1.76 & 1.78 & 0.27 & 0.5782 \\
\hline 12 & 1.57 & 2.01 & 1.80 & 0.36 & 0.5504 \\
\hline \multirow[t]{2}{*}{24} & 2.36 & 2.66 & 2.89 & 0.24 & 0.2463 \\
\hline & \multicolumn{4}{|c|}{$\cdots \cdots \cdots \cdots \cdots \cdots \cdots \cdots \cdots \cdots \cdots \cdots$} & \\
\hline 3 & 2.26 & 2.47 & 2.35 & 0.32 & 0.8221 \\
\hline 6 & 2.57 & 2.30 & 2.43 & 0.13 & 0.2522 \\
\hline 9 & 3.37 & 2.96 & 3.01 & 0.34 & 0.5027 \\
\hline 12 & 3.05 & 3.86 & 3.43 & 0.67 & 0.5473 \\
\hline \multirow[t]{2}{*}{24} & 4.73 & 5.05 & 5.41 & 0.29 & 0.2081 \\
\hline & \multicolumn{4}{|c|}{$\cdots \cdots \cdots \cdots \cdots \cdots \cdots \cdots \cdots \cdots$} & \\
\hline 3 & 70.46 & 76.49 & 73.59 & 10.21 & 0.8479 \\
\hline 6 & 97.85 & 83.96 & 89.67 & 4.69 & 0.1272 \\
\hline 9 & 97.36 & 98.43 & 102.36 & 12.03 & 0.7928 \\
\hline 12 & 106.94 & 119.50 & 108.13 & 20.81 & 0.6186 \\
\hline \multirow[t]{2}{*}{24} & 124.77 & 138.64 & 150.85 & 10.47 & 0.1857 \\
\hline & \multicolumn{4}{|c|}{ 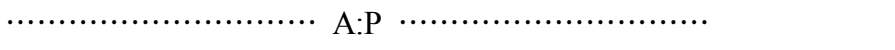 } & \\
\hline 3 & 2.58 & 2.56 & 2.64 & 0.05 & 0.3989 \\
\hline 6 & 2.61 & 2.45 & 2.51 & 0.10 & 0.3499 \\
\hline 9 & 2.55 & 2.57 & 2.60 & 0.05 & 0.5399 \\
\hline 12 & 2.76 & 2.71 & 2.71 & 0.09 & 0.8481 \\
\hline 24 & $2.51^{\mathrm{b}}$ & $2.53^{\mathrm{ab}}$ & $2.61^{\mathrm{a}}$ & 0.03 & 0.0469 \\
\hline
\end{tabular}

1) All values represent the mean of triplicates; ${ }^{2)}$ standard error of the mean;

${ }^{3) a, b}$ means in the same row with different superscripts $\operatorname{differ}(\mathrm{P}<0.05)$. 
Table 4. Effects of aqueous DFM supplementation levels on in vitro fibrolytic enzyme activities and dry matter disappearance

\begin{tabular}{|c|c|c|c|c|c|}
\hline \multirow{2}{*}{$\begin{array}{l}\text { Incubation time } \\
\qquad(\mathrm{hr})\end{array}$} & \multicolumn{3}{|c|}{ Treatments $^{1)}$} & \multirow{2}{*}{$\mathrm{SEM}^{2)}$} & \multirow{2}{*}{$P$-value } \\
\hline & Control & $0.025 \%$ & $0.05 \%$ & & \\
\hline \multicolumn{6}{|c|}{ 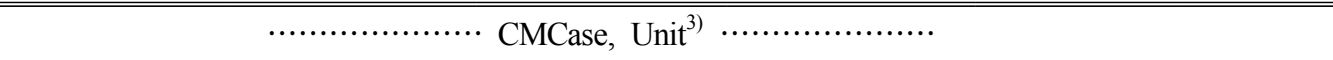 } \\
\hline 3 & 25.65 & 16.81 & 17.56 & 4.9169 & 0.2821 \\
\hline 6 & $15.09^{\mathrm{b} 4)}$ & $17.83^{\mathrm{a}}$ & $18.13^{\mathrm{a}}$ & 0.7576 & 0.0486 \\
\hline 9 & 15.57 & 17.84 & 17.18 & 1.0065 & 0.2133 \\
\hline 12 & 22.09 & 18.31 & 20.63 & 3.9707 & 0.6690 \\
\hline 24 & 18.80 & 20.10 & 19.80 & 0.9896 & 0.4801 \\
\hline \multicolumn{6}{|c|}{ 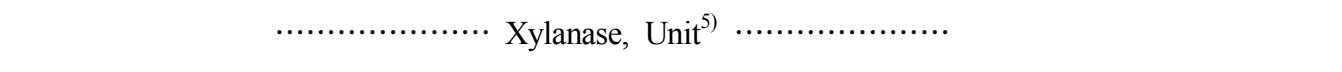 } \\
\hline 3 & 14.84 & 15.44 & 13.89 & 0.6878 & 0.2227 \\
\hline 6 & 15.60 & 15.27 & 14.74 & 0.4327 & 0.2793 \\
\hline 9 & 15.78 & 15.29 & 14.97 & 0.2962 & 0.1506 \\
\hline 12 & $15.78^{\mathrm{a}}$ & $13.70^{\mathrm{ab}}$ & $11.98^{\mathrm{b}}$ & 1.0462 & 0.0492 \\
\hline 24 & 12.20 & 11.17 & 14.74 & 2.3878 & 0.4175 \\
\hline \multicolumn{6}{|c|}{.............. DM disappearance $(\%)$.................. } \\
\hline 12 & 35.78 & 33.71 & 34.31 & 1.0425 & 0.2699 \\
\hline 24 & 54.51 & 55.20 & 54.88 & 0.6842 & 0.6410 \\
\hline
\end{tabular}

1) All values represent the mean of triplicates; ${ }^{2)}$ standard error of the mean; ${ }^{3)}$ one unit of CMCase activity equals $1 \mu \mathrm{mol}$ glucose/min./mL of ruminal fluid; ${ }^{4) a, b}$ means in the same row with different superscripts $\operatorname{differ}(\mathrm{P}<0.05) ;{ }^{5)}$ one unit of xylanase activity equals $1 \mu \mathrm{mol}$ xylose $/ \mathrm{min} . / \mathrm{mL}$ of ruminal fluid.

$\mathrm{DFM}$ 의 첨가로 효소활성과 건물소실율에도 유 의한 차이는 인정되지 않았다.

\section{2. 실험 2}

실험 2는 starch와 cellulose의 비율과 액상 $\mathrm{DFM}$ 의 첨가여부가 반추위내 발효와 섬유소분 해효소활성에 미치는 효과를 조사하였고, 반추 위내 $\mathrm{pH}$ 와 암모니아질소농도에 미치는 영향은 Table 5에 나타내었다.

Starch와 cellulose의 각 비율에 따른 액상 $\mathrm{DFM}$ 의 적용효과는 $\mathrm{pH}$ 와 암모니아질소농도에 전반적으로 유의한 차이를 나타내지 않았다. 하지만, 액상 $\mathrm{DFM}$ 의 첨가와는 상관없이 starch 와 cellulose의 비율에 따라서 부분적으로는 유 의한 차이를 나타내었다 $(\mathrm{P}<0.05)$. 즉, $s t a r c h$ 의 비율이 감소함에 따라 $\mathrm{pH}$ 가 증가하는 경향을 나타내었고, 배양 6시간의 70:30비율에서 액상
$\mathrm{DFM}$ 의 첨가가 다소 대조구보다 수치상의 감소 를 나타내었으며 $(\mathrm{P}>0.05)$, 배양 12시간의 50:50 비율에서는 오히려 대조구에서 유의하게 감소 하였다 $(\mathrm{P}<0.05)$. 액상 $\mathrm{DFM}$ 의 첨가가 $\mathrm{pH}$ 에 미치 는 영향은 경미하였고, 유의한 차이 또한 나타 나지 않았다. $\mathrm{pH}$ 에 대한 본 실험의 결과는 사 료로 공급되는 기질의 조성에 따른 영향이 강 한 반면 $\mathrm{DFM}$ 의 효과는 미약하다고 할 수 있 다.

한편 암모니아질소농도는 액상 $\mathrm{DFM}$ 의 첨가 와 starch 및 cellulose의 비율에 의하여 전반적 으로 유의한 영향을 받지 않았다. 하지만, 배양 9시간의 70:30비율에서 액상 DFM첨가구는 $35.65 \mathrm{mg} / \mathrm{dL}$ 의 암모니아질소농도를 나타내어 대 조구의 $65.05 \mathrm{mg} / \mathrm{dL}$ 에 비하여 유의하게 감소하 였다 $(\mathrm{P}<0.05)$. 본 실험에서는 배양기질의 질소 원으로서 비단백태질소인 요소를 사용하였고, 요소는 readily soluble nitrogen으로서 반추위내 
Lee et al. ; Effects of Aqueous DFM on In Vitro Fermentation

- 797 - 
에서 $\mathrm{NH}_{3}-\mathrm{N}$ 형태로 존재하며, 이는 미생물의 단 백질합성에 필요한 질소원으로 이용되기도 한 다. 다양한 $\mathrm{DFM}$ 에 관한 여러 보고에서, $\mathrm{DFM}$ 은 특정 반추위미생물에 선택적인 자극효과를 가지고, 미생물의 수를 증가시켜 미생물단백질 합성을 향상시키며, 아울러 미생물의 아미노산 조성을 변환시키는 효과가 있는 것으로 알려져 있다(Beharka와 Nagaraja, 1991; Dawson과 Hopkins, 1991; Erasmus 등, 1992). 하지만, 본 실험에서는 70:30비율에서 일부 암모니아질소 농도가 감소하였을 뿐, 전반적으로 유의한 효 과를 인정할 수 없었다.

액상 DFM이 starch와 cellulose비율에 따른 휘 발성지방산농도에 미치는 영향은 Table 6에 나 타내었다. Acetate농도는 DFM에 의한 유의한 효과가 나타나지 않았으나, starch의 비율이 증 가함에 따라 증가하는 경향이었다. 그리고 70:30의 starch와 cellulose비율에서 acetate생성이 유의하지는 않았지만 비교적 높은 수치를 나타 내었고, 배양 6시간에서는 70:30의 DFM적용구 에서 $60.77 \mathrm{mM}$ 로 대조구보다 유의하게 증가하 였다 $(\mathrm{P}<0.05)$.

Bach 등(1999)은 사료내 readily fermentable carbohydrate의 증가는 발효를 향상시키고, 미생 물에 충분한 에너지를 공급하여 미생물성장량 이 증가하고, 하부장관으로 이행하는 미생물 생산량이 증가한다고 하였고, 반추위내 $\mathrm{DFM}$ 의 첨가는 반추위발효양상을 변화시키는 것으로 알려져 있다(Gray와 Ryan, 1988). 본 실험에서 도 acetate의 증가는 아마도 반추위미생물 중 섬유소분해균의 자극효과에 의한 섬유소의 분 해결과인 것으로 사료된다. 하지만, 이와 반대 로, 다른 대부분의 in vitro 및 in vivo 연구는 $\mathrm{DFM}$ 이 휘발성지방산생성에 영향이 없는 것으 로 보고하였다(Carro 등, 1992; Caton 등, 1993; Fiems 등, 1993; Higginbotham 등, 1994).

한편, propionate, butyrate 및 valerate농도는 acetate와 유사한 양상의 결과를 나타내었고, 액 상 $\mathrm{DFM}$ 으로 인하여 70:30비율 등에서 부분적 으로 유의한 증가를 나타내었다 $(\mathrm{P}<0.05)$. 그리 고 cellulose비율이 $50 \%$ 이상으로 증가함에 따 라서는 $\mathrm{DFM}$ 의 효과가 나타나지 않았다. 액상
$\mathrm{DFM}$ 은 실제 급여환경에 따라 본 결과처럼 그 효과가 다양하게 나타날 수 있다고 생각된다. 그리고, 고능력우의 곡류위주사양 환경에서 본 실험에서 사용한 액상 $\mathrm{DFM}$ 의 첨가가 효과적일 것으로 사료된다.

Iso-acid생성량은 iso-butyrate농도가 DFM의 첨 가로 인하여 부분적으로 유의한 증가를 나타내 었다. 특히 70:30비율의 배양 3시간과 6시간에 서 유의한 증가를 나타내었고, 30:70비율의 배 양 24시간에서 유의한 증가를 나타내었다 $(\mathrm{P}<0.05)$. 하지만, 다른 비율에서는 증가하는 경 향만 나타낼 뿐 유의한 차이는 나타나지 않았 다. 이와 더불어 iso-valerate농도는 70:30비율의 $\mathrm{DFM}$ 첨가구에 대한 6시간과 9시간에서 1.94와 $3.13 \mathrm{mM}$ 로서 대조구의 1.32 와 $2.27 \mathrm{mM}$ 보다 유 의하게 높은 값을 나타내었고 $(\mathrm{P}<0.05)$, 다른 처 리구에서는 유의한 영향을 미치지 않았다. 총 휘발성지방산생산량은 각각의 휘발성지방산농

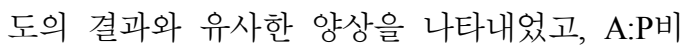
율은 액상 $\mathrm{DFM}$ 의 첨가로 70:30의 비율의 배양 9시간에서 대조구보다 유의하게 감소하였다 $(\mathrm{P}<0.05)$.

액상 DFM이 starch와 cellulose비율에 따른 섬 유소분해효소활성에 미치는 영향은 Table 7에 나타내었다. 섬유소분해효소활성은 액상 $\mathrm{DFM}$ 의 첨가로 CMCase 보다는 xylanase활성이 일부 유 의하게 증가하였으나 $(\mathrm{P}<0.05)$, 일관된 결과로 나타나지는 않았다. 그리고 xylanase는 배양시 간이 지속됨에 따라 그 활성은 감소하는 양상 을 나타내었고, 이는 발효가 지속됨에 따라 $\mathrm{pH}$ 감소로 인한 섬유소분해 미생물의 활성이 감소 하여 효소활성이 감소한 것으로 사료된다.

본 연구에서 나타난 결과는 $\mathrm{DFM}$ 의 효과보다 는 오히려 starch와 cellulose비율이 더 큰 영향 을 나타내었다. 여러 연구에서 $\mathrm{DFM}$ 이 반추위 내 발효성상에 유의한 효과는 나타나지 않는다 고 보고하였다(Feng 등, 1996; Beauchemin 등, 1999). 또한 Krause 등(1998)은 DFM의 효소제 제의 첨가는 전 장관섬유소소화율은 증가하지 만, 반추위내 $\mathrm{pH}$ 와 휘발성지방산농도에는 영향 을 미치지 않는다고 하여, $\mathrm{DFM}$ 의 작용은 반추 위내 뿐만 아니라 하부장관에서도 작용가능성이 
Lee et al. ; Effects of Aqueous DFM on In Vitro Fermentation

- 799 - 
Lee et al. ; Effects of Aqueous DFM on In Vitro Fermentation

$-800-$ 
Lee et al. ; Effects of Aqueous DFM on In Vitro Fermentation 
존재할 것으로 생각되고, 본 실험에서 사료적 조성에 따라 그 반응이 다양하게 나타나 이에 대한 더 많은 연구가 요구된다.

$$
\text { IV. 요 약 }
$$

본 연구는 액상 $\mathrm{DFM}($ Bacillus spp.)을 완전혼 합사료(실험 1) 및 다양한 비율의 $\mathrm{starch}$ 와 cellulose에 적용(실험 2) 하였을 때, 반추위내 발효와 섬유소분해효소활성에 미치는 영향을 평가하기 위해 in vitro 배양을 24시간동안 실시 하였다. 실험 1 의 처리구는 완전혼합사료에 액 상 $\mathrm{DFM} 0 \%$ (대조구) $0.025 \%, 0.05 \%$ 로 각각 첨 가하였다.

실험 1 에서, $0.025 \%$ 구는 배양 6,9 시간에서 대조구와는 유의한 차이가 없었으나, $0.05 \%$ 구 보다는 유의하게 낮은 결과를 보였다 $(\mathrm{P}<0.05)$. 암모니아질소농도와 휘발성지방산농도는 액상 $\mathrm{DFM}$ 에 의하여 영향을 받지 않았다. 하지만, $\mathrm{A}: \mathrm{P}$ 비율은 $\mathrm{DFM}$ 의 적용으로 배양 24 시간에 대 조구에 비하여 $0.05 \%$ 구에서 유의한 증가를 나 타내었다 $(\mathrm{P}<0.05)$. 액상 $\mathrm{DFM}$ 적용에 의한 섬유 소분해효소활력은 전반적으로 유의한 효과가 나타나지 않았지만, CMCase는 배양 6시간에 대조구에 비하여 유의한 증가를 나타내었다 $(\mathrm{P}<0.05)$. 하지만, xylanase는 배양 12시간의 $0.05 \%$ 구에서 오히려 액상 $\mathrm{DFM}$ 의 적용으로 유 의하게 감소하였다 $(\mathrm{P}<0.05)$. 반추위내 건물소실 율은 액상 $\mathrm{DFM}$ 의 첨가수준에 의해 유의한 차 이가 나타나지 않았다.

실험 2는 다양한 비율(90:10, 70:30, 50:50, $30: 70,10: 90)$ 의 starch와 cellulose에 액상 DFM 을 각 비율에 대하여 대조구 $(0 \%)$ 와 첨가구 $(0.025 \%)$ 로 나누어 반추위액을 이용하여 배양 하였다.

반추위내 $\mathrm{pH}$ 는 액상 $\mathrm{DFM}$ 의 첨가로 유의한 영향을 받지 않았고, starch의 비율이 증가함에 따라 부분적으로 유의하게 감소하였다 $(\mathrm{P}<0.05)$. 암모니아질소농도는 액상 $\mathrm{DFM}$ 의 첨가와 starch 및 cellulose의 비율에 의하여 유의한 영향을 받 지 않았다. 하지만, 배양 9시간의 70:30비율에 서 액상 $\mathrm{DFM}$ 첨가구가 $35.65 \mathrm{mg} / \mathrm{dL}$ 의 암모니아
질소농도를 나타내어 대조구의 $65.05 \mathrm{mg} / \mathrm{dL}$ 에 비하여 유의하게 감소하였다 $(\mathrm{P}<0.05)$. 휘발성지 방산농도는 70:30비율의 6시간 배양에서 액상 $\mathrm{DFM}$ 구가 대조구에 비하여 유의한 증가를 나타 내었다 $(\mathrm{P}<0.05)$. 액상 $\mathrm{DFM}$ 의 첨가는 $\mathrm{CMCase}$ 에 는 전반적으로 유의한 영향을 미치지 않았다. 그러나 xylanase에는 90:10, 30:70 및 10:90구에 서 부분적인 유의성이 인정되었다.

본 연구결과로부터, 액상 $\mathrm{DFM}$ 의 적용은 in vitro 발효성상과 섬유소분해효소활성을 유의적 으로 향상시키지 않았고, 사료의 조성에 따라 그 효과는 다양하게 나타나 일관성이 없는 것 으로 평가되었다.

\section{V. 인 용 문 헌}

1. AOAC. 1995. Official Methods of Analysis. 16th ed. Association of Official Analytical Chemists, Washington, DC.

2. Arambel, M. J. and Wiedmeier, R. D. 1986. Effect of supplemental Saccharomyces cerevisiae and/or Aspergillus oryzae on rumen fermentation. J. Dairy Sci. 69(Suppl. 1):188.(Abstr.)

3. Bach, A., Yoon, I. K., Stern, M. D., Jung, H. G. and Chester-Jones, H. 1999. Effects of type of carbohydrate supplementation to lush pasture on microbial fermentation in continuous culture. J. Dairy Sci. 82:153-160.

4. Beauchemin, K. A., Morgavi, D. P., McAllister, T. A., Yang, W. Z. and Rode, L. M. 2001. The use of enzymes in ruminant diets:In Recent advances in animal nutrition, pp. 297-322. Edited by P. C. Garnsworthy and D. J. A. Cole. Nottingham. Univ. Press.

5. Beauchemin, K. A., Yang, W. Z. and Rode, L. M. 1999. Effects of grain source and enzyme additive on site and extent of nutrient digestion in dairy cows. J. Dairy Sci. 82:378-390.

6. Beharka, A. A. and Nagaraja, T. G. 1991. Effects of Aspergillus oryzae extract(AMAFERM) on ruminal fibrolytic bacteria and in vitro fiber degradation. Page 32 in Abstracts of 21st Biennial Conference on Rumen Function. Chicago, IL.

7. Carro, M. D., Lebzien, P. and Rohr, K. 1992. 
Effects of yeast culture on rumen fermentation, digestibility and duodenal flow in dairy cows fed a silage based diet. Livest. Prod. Sci. 32:219-229.

8. Caton, J. S., Erickson, D. O., Carey, D. A. and Ulmer, D. L. 1993. Influence of Aspergillus oryzae fermentation extract on forage intake, site of digestion, in situ degradability and duodenal amino acid flow in steers grazing cool-season pasture. J. Anim. Sci. 71:779-787.

9. Chaney, A. L. and Marbach, E. P. 1962. Modified reagents for determination of urea and ammonia. Clin. Biochem. 8:130-132.

10. Dawson, K. A. and Hopkins, D. M. 1991. Differential effects of live yeast on the cellulolytic activities of anaerobic ruminal bacteria. J. Anim. Sci. 69 (Suppl. 1):531.

11. Duncan, D. B. 1955. Multiple range and multiple F test. Biometrics 11:1-42.

12. Erasmus, L. J., Botha, P. M. and Kistner, A. 1992. Effect of yeast culture supplement on production, rumen fermentation, and duodenal nitrogen flow in dairy cows. J. Dairy Sci. 75: 3056-3065.

13. Erwin, E. S., Marco, S. J. and Emery, E. M. 1961. Volatile fatty acid analysis of blood and rumen fluid by gas chromatography. J. Dairy Sci. 44:1768-1771.

14. Feng, P., Hunt, C. W., Pritchard, G. T. and Julien, W. E. 1996. Effect of enzymes preparations on in situ and in vitro degradation and in vivo digestive characteristics of mature cool-season grass forage in beef steers. J. Anim. Sci. 74: 1349-1357.

15. Fiems, L. O., Cottyn, B. G., Dussert, L. and Vanacker, J. M. 1993. Effect of a viable yeast culture on digestibility and rumen fermentation in sheep fed different types of diets. Reprod. Nutr. Dev. 33:43-49.

16. Freter, R. 1992. Factors affecting the microecology of the gut. In: R. Fuller (Ed.) Probiotics: The Scientific Basis. pp 111-144. Chapman \& Hall, London.

17. Gray, W. R. and Ryan, J. P. 1988. A study of the effect of yeast culturye on ruminal fermentation in sheep. Page 129 in Biotechnology in the Feed Industry. T. P. Lyons, ed. Alltech Technical
Publications, Nicholasville, KY.

18. Hentges, D. J. 1992. Gut flora in disease resistance. In: R. Fuller (Ed.) Probiotics: The Scientific Basis. pp 87-110. Chapman \& Hall, London.

19. Higginbotham, G. E., Collar, C. A., Aseltine, M. S. and Bath, D. L. 1994. Effect of yeast culture and Aspergillus oryzae extract on milk yield in a commercial dairy herd. J. Dairy Sci. 77:343-348.

20. Hristov, A. N., McAllister, T. A. and Cheng, K. J. 1998. Effect of dietary or abomasal supplementation of exogenous polysaccharide-degrading enzymes on rumen fermentation and nutrient digestibility. J. Anim. Sci. 76:3146-3156.

21. Hristov, A. N., McAllister, T. A. and Cheng, K. J. 2000. Intraruminal supplementation with increasing levels of exogenous polysaccharide-degrading enzymes: effects on nutrient digestion in cattle fed a barley grain diet. J. Anim. Sci. 78:477-487.

22. Jonsson, E. and Conway, P. 1992. Probiotics for pigs. In: R. Fuller (Ed.) Probiotics: The Scientific Basis. pp 260-316. Chapman \& Hall, London.

23. Jalc, D., Baran, M., Vendrak, T. and Siroka, P. 1991. The effect of monensin on the fermentation of feed with different hay and concentrate proportions in (Rusitec) rumen pouch. Vet. Medicina 36:29-38.

24. Jenny, B. F., Vandijk, H. J. and Collins, J. A. 1991. Performance and fecal flora of calves fed a Bacillus subtilis concentrate. J. Dairy Sci. 74: 1968-1973.

25. Kalogridou-Vassiliadou, D. 1992. Biochemical activities of Bacillus species isolated from flat sour evaporated milk. J. Dairy Sci. 75:2681-2686.

26. Krause, M., Beauchemin, K. A., Rode, L. M., Farr, B. I. and Norgaard, P. 1998. Fibrolytic enzyme treatment of barley grain and source of forage in high-grain diets fed to growing cattle. J. Anim. Sci. 76:2912-2920.

27. Kung, L. 2001. Developments in rumen fermentation-commercial applications : In Recent advances in animal nutrition, pp. 281-295. Edited by P. C. Garnsworthy and D. J. A. Cole. Nottingham. Univ. Press.

28. Luchini, N. D., Broderick, G. A. and Combs, D. K. 1996. Characterization of the proteolytic activity of commercial proteases and strained 
ruminal fluid. J. Anim. Sci. 74:685-692.

29. Maeng, W. J., Van Nevel, C. J., Baldwin, R. L. and Morris, J. G. 1976. Rumen microbial growth rates and yields: Effect of amino acids and protein. J. Dairy Sci. 59:68-79.

30. McAllister, T. A., Oosting, S. J., Popp, J. D., Mir, Z., Yanke, L. J., Hristov, A. N., Treacher, R. J. and Cheng, K. -J. 1999. Effect of exogenous enzymes on digestibility of barley silage and growth performance of feedlot cattle. Can. J. Anim. Sci. 79:353-360.

31. Miles, R. D. and Bootwalla, S. M. 1991. Directfed microbials in avian. In: Direct-Fed Microbials in Animal Production. A review of literature. Page 117 in Natl. Feed Ingred. Assoc., West Des Moines, IA.

32. Miller, G. M. 1959. Use of dinitrosalicylic acid reagent for determination of reducing sugar. Anal. Chem. 31:426-428.

33. Perdigon, G. and Alvarez, S. 1992. Bacterial interactions in the gut. In: R. Fuller (Ed.) Probiotics: The Scientific Basis. pp 146-180. Chapman \& Hall, London.

34. Phipps, R. H., Sutton, J. D., Bhat, M. K., Hartnell, G. F., Vicini, J. and Hard, D. L. 2000. Effect of cell-wall degrading enzymes and method of application on feed intake and milk production of Holstein-Friesian dairy cows. J. Dairy Sci. 83(Suppl. 1):236-237(Abstr.)

35. Rode L. M., Yang, W. Z. and Beauchemin, K. A. 1999. Fibrolytic enzyme supplements for dairy cows in early lactation. J. Dairy Sci. 82:21212126.

36. Rojo, R., Mendoza, G. D., González, S. S., Landois, L., Bárcena, R. and Crosby, M. M. 2005. Effects of exogenous amylases from Bacillus licheniformis and Aspergillus niger on ruminal starch digestion and lamb performance. Anim. Feed Sci. Technol. In press.

37. Rust, J. W., Jacobson, N. L., McGillard, A. D. and Hotchkiss, D. K. 1965. Supplementation of dairy calf diets with enzymes. II. Effect on nutrient utilization and on composition of rumen fluid. J. Anim. Sci. 24:156-160.
38. SAS. 2000. SAS/STAT ${ }^{\circledR}$ User's guide (Release 8.1 ed.). Statistics, SAS Inst, Inc., Cary, NC.

39. Sauer, F. D., Kramer, J. K. G. and Cantwell, W. J. 1989. Antiketogenic effects of monensin in early lactation. J. Dairy Sci. 72:436-442.

40. Steel, R. G. D. and Torrie, J. H. 1980. Principles and procedures of statistics. A biometrical approach (2nd eds.). McGraw-Hill, Inc.

41. Sutton, J. D., Phipps, R. H., Beever, D. E., Humphries, D. J., Hartnell, G. F., Vicini, J. L. and Hard, D. L. 2003. Effect of method of application of a fibrolytic enzyme product on digestive processes and milk production in Holstein-Friesian cows. J. Dairy Sci. 86:546-556.

42. Tilley, J. M. A. and Terry, R. A. 1963. A two-stage technique for the in vitro digestion of forage crops. J. Br. Grassl. Soc. 18:104-111.

43. Van Soest, P. J., Roberts, J. B. and Lewis, B. A. 1991. Methods for dietary fiber, neutral detergent fiber, and non-starch polysaccharides in relation to animal nutrition. J. Dairy Sci. 74:3583-3597.

44. Wang, Y., McAllister, T. A., Rode, L. M., Beauchemin, K. A., Morgavi, D. P., Nsereko, V. L., Iwaasa, A. D. and Yang, W. Z. 2001. Effects of an exogenous enzyme preparation on microbial protein synthesis, enzyme activity and attachment to feed in the rumen simulation technique (Rusitec). Br. J. Nutr. 85:325-332.

45. Yang, W. Z., Beauchemin, K. A. and Rode, L. M. 1999. Effects of an enzyme feed additive on extent of digestion and milk production of lactating dairy cows. J. Dairy Sci. 82:391-403.

46. Yang, W. Z., Beauchemin, K. A. and Rode, L. M. 2000. A comparison of methods of adding fibrolytic enzymes to lactating cow diets. J. Dairy Sci. 83:2512-2520.

47. Yoon, I. K. and Stern, M. D. 1995. Influence of direct-fed microbials on ruminal microbial fermentation and performance of ruminants: A review. Asian-Aust. J. Anim. Sci. 8:533-555.

(접수일자 : 2005. 6. 28. / 채택일자 : 2005. 9. 30.) 